\title{
Nature's Schoolhouse
}

Boys and girls will still have one more opportunity to win a valuable nature field guide, by submitting an essay for the next issue. All entries which have been or will be printed in THE BLUE JAY, are also eligible for the grand prize, the $\$ 50$ camera, donated by Bird Films. This prize will be awarded in June or July.

Here are the rules of the contest. Write an original story of one of your nature observations. Confine it to less than 500 words. Send your name, address, age, grade and school to the editor, L. T.
Carmichael, 1077 Garne for the reception of $\mathrm{m}$ will be April 15, 1955.

A choice of Peterson's mals or butterflies) o plus a subscription to given as a prize for $t$ the next issue. At their award several addition: your story please indica

PRIZE WINNERS:

\section{The Flight Song of the Prairie Horned Lark}

\author{
By LAVERNE WENDELL, MacNutt, Sask. \\ Age 14, Grade 9
}

Drawing by Robert Seibert (Audubon Magazine)

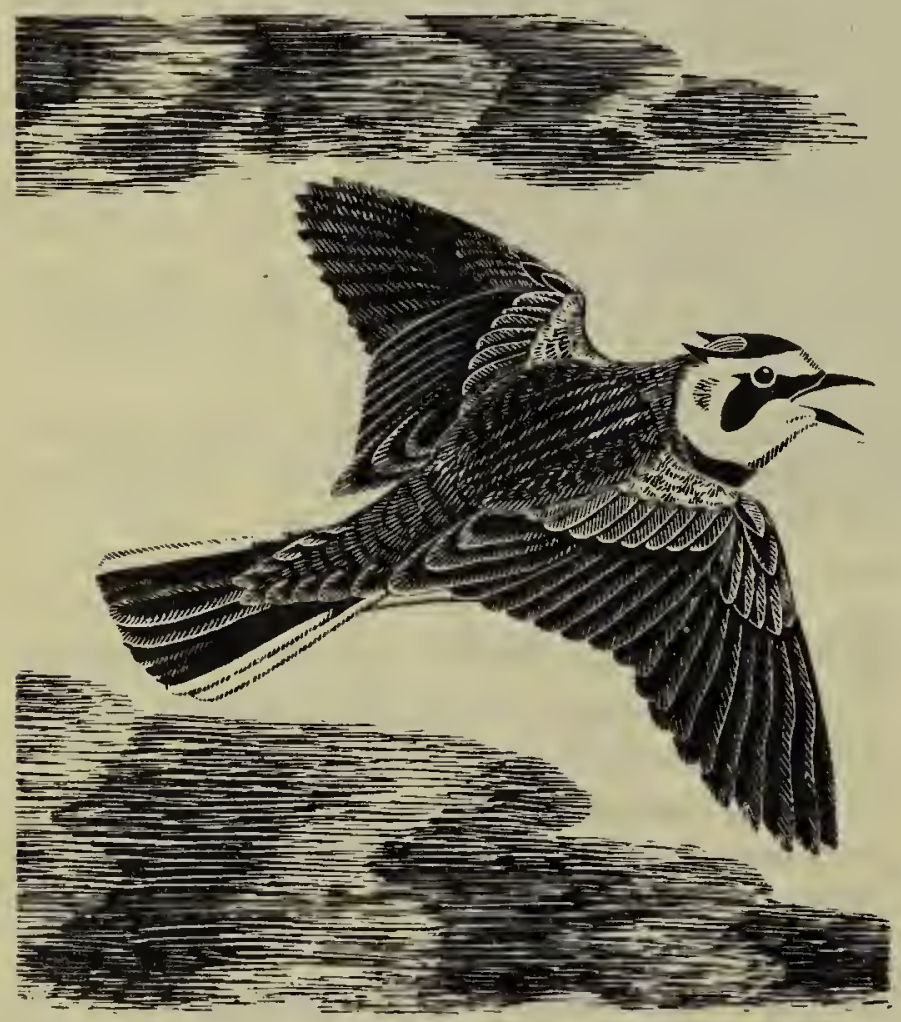

Hail to thee, blithe Spirit! Bird thou never wert,

That from Heaven, or near it, Pourest thy full heart

In profuse strains of unpremeditated art.

One afternoon, late in June, while. driving along a country road, Dad suddenly stopped the truck and told me to watch a Horned Lark which was rising by the side of the road. It rapidly gained elevation through consecutive spurts and glides till it had reached a height of what seemed to be about two hundred feet. I thought it would fly away, but Dad who had witnessed this performance before, assured me that it would circle and told me to listen closely when it spread its wings.

At first I couldn't hear anything but after a while I distinctly heard the song of the Horned Lark that one so commonly hears with its return in the spring of the year. This performance continued for about five or ten minutes after which it unexpectedly folded its wings and, in dive bomber fashion, dropped straight down giving the impression that it must crash headfirst into the ground. With less than ten feet from the ground, and while I was holding my breath for the crash, its wings suddenly opened and gliding a few short feet away it sat down as though it hadn't performed at all. This performance is rarely seen. It was the first time I had ever witnessed the strange flight and common song of the Horned Lark way up in the sky. Dad told me he had the pleasure of seeing and hearing it on two or three other occasions many years ago.

As we drove home I felt considerably thrilled that I had witnessed this rare flight song of the Horned Lark. I hoped that in the not too distant future I might again have the opportunity of being audience to the Horned Lark's performance. 


\section{oys' and Girls' Section}

Regina. The deadline al for the next issue

d Guides (birds, mamherry's Flower Guide, BLUE JAY will be est story received for retion the judges may izes. When submitting bur choice of prize.

y Houston and Cliff
Shaw, of Yorkton, have judged the essays sumitted for this issue. The first prize, "The Flight Song of the Prairie Horned Lark" goes to Laverne Wendell; the second prize, "The Two Bluebirds" to Evelyn Mess; the third prize, "Wild Geese" to Bill Greschuk. Field Guides will be mailed to each of these winners.

Note for Society Members: Will those willing to donate three dollars as a prize for this or the next contest, please contact Dr. Stuart Houston, Box 278, Yorkton.

\section{The Two Bluebirds}

\section{By EVELYN MESS, Box 189, Saltcoats, Sask.}

Age 13, Grade 7, Chatsworth School

Two bluebirds built their nest in our binder twine box on the binder. They had four blue eggs.

Soon it came time when the men had to cut the grain, and while they were fixing the binder the bluebirds wanted in their nest. So not wanting to destroy the nest, Grandad got another old binder twine box, put the nest in it and hung it up in a tree near the binder.

At first the bluebirds just flew around it, but soon the male bird got brave and went in the nest for a few minutes. Then the female had a look in. As soon as the men moved the binder, she went in and stayed on the nest. In two days time four little bluebirds had hatched. Soon they learned to fly. They stayed around till it was time to go south. They wers so interesting I hope they come back next year.

\section{Wild Geese}

By BILL GRESCHUK, Box 235, Two Hills, Alberta Age 13, Grade 7, Two Hills School

My story will deal with wild geese. One incident is very unusual. The other is very interesting.

About three years ago wild geese nested by our lake. This in itself was not unusual except for the fact that one goose made her nest on a tree. We all watched with interest. The eggs were laid and the "setting" had begun. In due time the eggs hatched and the nest was full of hungry goslings. We waited with keen anticipation for the time that the goslings would be ready to leave the nest. We wanted to see how they would get down the tree. The very thought of missing that sight was a veritable nightmare. Well most everybody thought that the goslings would remain in the nest till they were ready to fly. I thought so too. But I was wrong and I was very, very lucky, for I was, so to speak, on the ground floor when it was time for the goslings to leave the nest. I was awakened one morning very carly, because the calves got out. One was by the tree where the goslings were. When I got to the calf, I saw how the goslings got down from the nest. They were pushed off by the mother and fell to the ground unhurt.

Last fall I noticed a very beautiful wild goose panorama. The geese were migrating. A first wave came along and flew over our house. Then they (Continued on Page 25) 